\author{
Wojciech Browarny (iD https://orcid.org/0000-0002-4829-2351 \\ Uniwersytet Wrocławski \\ wojciech.browarny@uwr.edu.pl
}

\title{
„Kartki” Tadeusza Różewicza
}

\section{Tadeusz Różewicz’s “Postcards”}

\begin{abstract}
The article discusses Tadeusz Różewicz's prose from the perspective of "postcards" as a compositional and skill-training format closely connected with the writer's autobiographical output. The author of the article traces the presence and transformations of "postcards" in Różewicz's fiction and, perhaps most importantly, in his lesser-known works: his journal, travel essays, memoir sketches, and metaliterary pieces. The aim of the article is to demonstrate that "postcards" appeared in Różewicz's writing throughout his career, from his debut until his mature output, with this conclusion confirmed even by a brief overview of the writer's oeuvre. The author seeks to prove that the "postcards" are a complex and consistently applied writing technique which serves, among others, to compose pieces and imbue them with reflections on writing itself. They are also a tool for the author's self-creation, an intermediary between his texts and the autobiography (re)constructed therein, a means in which his subjectivity and historical and existential experience become present in his writing.
\end{abstract}

Keywords: Tadeusz Różewicz, "postcards”, Polish prose, autobiography, literary skill

Streszczenie: Artykuł „Kartki” Tadeusza Różewicza opisuje prozę pisarza z perspektywy „kartek” jako formuły kompozycyjno-warsztatowej, związanej jednak ściśle z jego praktyką autobiograficzną. Autor artykułu śledzi obecność i przemiany „kartek” w utworach fabularnych Tadeusza Różewicza, ale przede wszystkim w jego mniej znanych dziełach: dzienniku, reportażach podróżniczych, szkicach wspomnieniowych i metaliterackich. Celem artykułu nie jest udowodnienie, że „kartki” występują w pisarstwie Różewicza od momentu jego debiutu do okresu dojrzałej twórczości, gdy nawet jej pobieżny przegląd potwierdza tę oczywistość. Autor stara się dowieść, że „kartki” są złożoną i konsekwentnie stosowaną techniką pisarską, która służy między innymi do komponowania utworów i nasycania ich refleksją warsztatową. Są one również narzędziem autokreacji pisarza, medium między jego tekstami i (re)konstruowaną w nich autobiografią, sposobem uobecniania się w nich jego podmiotowości oraz doświadczenia historycznego i egzystencjalnego.

Słowa kluczowe: Tadeusz Różewicz, „kartki”, proza polska, autobiografia, warsztat pisarski 
Tadeusz Różewicz był poetą, dramatopisarzem i prozaikiem, a proza stanowi obszerną oraz najbardziej zróżnicowaną gatunkowo część jego dorobku. Autor Śmierci w starych dekoracjach tworzył minipowieści, nowele i opowiadania, lecz równie ważne miejsce w jego prozie zajmują teksty niefikcjonalne: reportaże, felietony, notatki, szkice, eseje, listy, wspomnienia i zapiski dziennika. Tematyczne klasyfikacje utworów Różewicza odwoływały się najczęściej do kilku głównych wątków jego pisarstwa: partyzanckiego i okupacyjnego, chińskiego lub włoskiego, rodzinnego czy autobiograficznego. Tropem wyznaczonym przez Kazimierza Wykę rozpoznano i opisano ich kolejne realizacje w różnych gatunkach lub rodzajach literackich, akcentując w ten sposób problemową integralność twórczości Różewicza. Mniej uwagi poświęcano metaliterackiemu oraz warsztatowemu wymiarowi tej ciągłości w jego prozie, konsekwentnej pracy pisarza nad formą jego utworów narracyjnych, relacjom między jej genologiczną różnorodnością i historyczną zmiennością a trwałymi rozwiązaniami, które rozwijał przez wiele lat. Jednym z tych rozwiązań były „kartki”. Tak autor Niepokoju nazywał niektóre swoje nowele, szkice lub fragmenty dziennika, począwszy od konspiracyjnego debiutu do okresu późnej twórczości. Znaczenie „kartek” nie sprowadzało się jednak tylko do tytułów. Różewicz wykorzystywał je także do projektowania kompozycji swoich tekstów oraz związków między utworami. „Kartki” są obecne między innymi w strukturze jego partyzanckiego debiutu, reportażach i opublikowanych fragmentach dziennika. Ten artykuł przedstawia historię „kartek” i ich miejsce w jego prozie.

\section{Kartki z bloku meldunkowego}

Różewicz debiutował parokrotnie. Tom wierszy Niepokój poprzedziły przedwojenne juwenilia, nowele i artykuły publikowane w konspiracji oraz utwory satyryczne wydane w 1946 roku. „Kartki” pojawiły się po raz pierwszy w cyklu „Z żołnierskiego dziennika kartki ulotne”, drukowanym pod pseudonimem Satyr na łamach częstochowskiego „Czynu Zbrojnego”, podziemnego czasopisma Armii Krajowej. Nowele ogłaszane w tym piśmie Różewicz włączył do debiutanckiego zbioru Echa leśne, opublikowanego na powielaczu w 1944 roku, który uzupełnił kilkoma utworami lirycznymi i partyzanckimi humoreskami.

Heroiczna i podniosła pierwsza część tej książki jest wprowadzona śródtytułem Kamienie na szaniec, podkreślającym jej romantyczny i konspiracyjny patronat. Kolejna (druga) nosi tytuł Kartki zpamiętnika i zawiera utwory o różnych doświadczeniach leśnej partyzantki: akcjach, ranach, rekwizycjach, kłopotach wychowawczych i warunkach higienicznych. Tej części patronuje starszy brat pisarza, Janusz Różewicz, poeta i oficer wywiadu AK, którego wiersz Kartka z bloku meldunkowego jest umieszczony w jej środku. Kartki z pamiętnika czerpią z prozaicznej poetyki wojskowego raportu, minibiografii żołnierza z poboru, 
naturalistycznego obrazka z życia oddziału. Mimo bohaterskiego i wysokoartystycznego patronatu zbliżają się do formuły prozy okazjonalnej, użytkowej, żartobliwej lub dokumentacyjnej. Są polifoniczne i stylistycznie różnorodne. Adekwatne do wielowymiarowej kondycji Różewiczowskiego partyzanta: publicznej i prywatnej, cywilnej i militarnej, historycznej i egzystencjalnej, nadzwyczajnej i wzniosłej, ale jednocześnie cielesnej, ulotnej i pospolitej. Granice między tymi doświadczeniami są płynne, a jednoznaczna hierarchia wartości z pierwszej części tomu ustępuje miejsca relacjom wielostronnym. Autorytet „kartek” jest motywowany odgórnie: patriotycznym imperatywem i związanym z nim literackim idiomem, a także oddolnie: autentyzmem i konkretem partyzanckiej codzienności.

„Kartki” jako polowy quasi-gatunek prozy Różewicza wywodzą się z historycznego i przestrzennego kontekstu jego debiutu. Szczególnie reprezentowane w Echach leśnych są oczywiście miejsca zlokalizowane na marginesie cywilizacji lub w środowisku naturalnym, takim jak las, polana, obóz partyzancki lub ziemianka. Funkcjonują one jako przestrzeń przyrodnicza, nasycona jednak wartościami kulturowymi, historiozoficznymi i etycznymi. Natura w tej prozie jawi się jako cenna i przyjazna nie tylko dlatego, że stanowi fizyczne schronienie i zaspokaja biologiczne potrzeby człowieka, ale przede wszystkim dlatego, że jest bardziej „ludzka” i „polska” niż przestrzeń miejska czy społeczeństwo. To, co obce i nieludzkie, pozostaje bowiem na zewnątrz leśnego azylu, który mimo zimna, głodu, brudu i wszy okazuje się enklawą sensu i wiary w przyszłość. Chociaż bywa mizantropijna i antycywilizacyjna, podmiotowa perspektywa debiutanckich „kartek” Różewicza pozostaje antropocentryczna.

\section{Kartki z notesu reportera}

Jako pisarz i reporter Różewicz często podróżował po kraju i wyjeżdżał za granicę. Jego pierwszymi reporterskimi wyprawami były wyjazdy na Ziemie Odzyskane i podróże do państw socjalistycznych. W 1947 roku opublikował w „Trybunie Tygodnia” ${ }^{\prime}$ trzyczęściowy reportaż o transporcie mostu odrzańską drogą wodną z Koźla do Szczecina, a rok później w tej samej gazecie reporterski tekst poświęcony pracy wolińskich rybaków. Sprawy podjęte w tych relacjach należały do ówczesnego kanonu tematów dziennikarskich, powiązanych z niemieckimi terytoriami, które po 1945 roku zostały włączone do polskiego państwa w jego pojałtańskim kształcie. Autor reportaży Most ptynie do Szczecina, Spacer

1 „Trybuna Tygodnia” - niedzielny dodatek „Trybuny Robotniczej”, organu Śląskiego Komitetu Wojewódzkiego Polskiej Partii Robotniczej w Katowicach. 
po Opolu i Światta na drodze oraz Wyprawa na ztota rybkę przedstawił zarys piastowskiej przeszłości tych ziem, sytuację autochtonów i osadników z różnych stron kraju, cywilizacyjną specyfikę lokalnej infrastruktury i urbanisty$\mathrm{ki}$, a przede wszystkim perspektywę odbudowy z ruin, gospodarczego wykorzystania i polonizacji ${ }^{3}$.

Charakterystyczne cechy poetyki tych tekstów wywodzą się z warunków i okoliczności reporterskiej pracy w terenie. Scenerię dziennikarskiej wyprawy Różewicza tworzą Odra i Dziwna, łącząca Zalew Szczeciński z Bałtykiem, pływające po nich statki i barki transportowe, kutry, motorówki i łodzie, oglądane po drodze śluzy, porty lub stocznie. Jego bohaterowie to starzy odrzańscy szyprowie, wolińscy rybacy, rolnicy i robotnicy, którzy ciężko pracują na spustoszonych i zdziczałych Ziemiach Zachodnich. Autor tych reportaży towarzyszy im w codziennych zajęciach, rozmawia z nimi, przygląda się ich aparycji i gestom oraz skromnemu inwentarzowi kajut lub mieszkań. $\mathrm{Na}$ „kartce z prywatnego notesu" skrupulatnie notuje malarską kolorystykę słońca zachodzącego nad zalewem, szukając klucza do „prawdy” w tekście dziennikarskim. Gdyby ten fragment Wyprawy na ztotą rybkę czytać jako pisarski instruktaż, kluczem byłby rzeczowy, miejscami wręcz protokolarny, a jednocześnie na tyle obrazowy język, by trafnie oddać nie tylko statyczny kształt i barwę rzeczywistości, czyli życia i pracy bohaterów reportażu, lecz także dynamiczne tempo zmian, którym podlegają ludzie w tym nowym, trudnym i obiecującym kraju.

Język postulowany w reporterskich „kartkach” Różewicza jest echem awangardowej praktyki poetyckiej, nastawionej na funkcjonalność, precyzję, stylistyczną adekwatność i podsycanie wyobraźni. Jest także efektem trwającej od kilku dekad wymiany środków wyrazu między prozą artystyczno-fabularną i dokumentalną oraz krytycznej dyskusji o reportażu jako nowoczesnym gatunku literacko-użytkowym. Stanowi wreszcie odpowiedź na powojenną potrzebę dawania wiarygodnego świadectwa niebywałym wydarzeniom historycznym oraz szybkim przemianom społecznym i cywilizacyjnym połowy XX wieku. Kryteria tematyzowane lub sugerowane w reportażu z 1948 roku można też odczytać jako warsztatową polemikę z doktryną socrealizmu, która zdefiniowała, a wkrótce administracyjnie narzuciła schemat przedstawiania człowieka pracującego i przemian epoki. Fałszywej heroizacji, ideologicznej instrumentalizacji oraz naiwnej egzotyzacji pracy w literaturze polskiej późnych lat czterdziestych Różewicz przeciwstawił „kartkę z prywatnego notesu” reportera, który sięga do rozwiązań malarskich i awangardowych. Łączy kreatywność pisarza

2 T. Różewicz, Most plynie do Szczecina, „Trybuna Tygodnia” 1947, nr 9; tenże, Spacer po Opolu, „Trybuna Tygodnia” 1947, nr 10; tenże, Światta na drodze, „Trybuna Tygodnia” 1947, nr 11; tenże, Wyprawa na ztota rybke, „Trybuna Tygodnia” 1948, nr 33 i 35.

3 Zob. W. Browarny, Nadodrze Tadeusza Różewicza: o reportażu „Most plynie do Szczecina”, „Czytanie Literatury: łódzkie studia literaturoznawcze” 2013, nr 2. 
z odpowiedzialnością dokumentarysty, uczestnika i świadka, trzymającego się faktów i słuchającego ludzi.

Kartki z Wegier, tom reportaży, szkiców i zapisków dziennika opublikowany w 1953 roku, powstał pod naciskiem doktryny socrealizmu. Różewicz przebywał na Węgrzech w 1950 roku i na początku następnego roku. Korzystając z wymiany kulturalnej między krajami socjalistycznymi, uczył się języka węgierskiego, obejrzał wystawę muzealną poświęconą ruchowi robotniczemu, odwiedził budowę przemysłowego ośrodka Sztálinváros, spółdzielnię rolniczą i górnicze miasto, a także Budapeszt i Pusztę. Między najbardziej sztampowymi fragmentami zbioru, napisanymi w konwencji produkcyjniaka, autor Kartek z Wegier zmieścił jednak sporo nieoczywistych sytuacji i postaci, które nie pasowały do wytycznych realizmu socjalistycznego ${ }^{4}$. Starość, samotność, traumatyczna pamięć, prywatność lub obojętność na ideologię nowego ustroju - zauważone przez reportera - nie stanowią tylko dyżurnej przeciwwagi dla obrazów cywilizacyjnego postępu, społecznego zaangażowania czy politycznej prawomyślności, lecz są opisane z uważnością i zaciekawieniem.

Autor tej książki nie podejmuje otwartej krytyki węgierskiej rzeczywistości połowy XX wieku. Nie tylko dlatego, że było to politycznie niedopuszczalne, ale także dlatego, że przeważnie akceptuje socjalistyczny kierunek przemian tego kraju. Jego zastrzeżenia i wątpliwości dochodzą do głosu w rozwiązaniach warsztatowych. Teksty zamieszczone w tomie pod względem gatunkowym okazują się zróżnicowane, a kompozycja jest niedomknięta. Uwidocznia się to w Kartkach z dziennika, ostatniej części zbioru, które są - bardziej niż poprzednie części - prywatne, subiektywne i dialogiczne, a przy tym w wielu miejscach autentyczne i realistyczne. Kartki z dziennika jako zakończenie i egzystencjalna (dziennikowa) sygnatura dzieła uruchamiają dyskretną dwuznaczność całości. Sprawiają wrażenie, jakby ich autor próbował między wierszami frazesów i propagandy odzyskać własny głos, umocowany w biograficznym konkrecie. Tom Różewicza podlega dominującej metodzie literackiej, ale czytany od strony dziennikowych „kartek” ujawnia ostrożną grę pisarza z narzuconym schematyzmem i fałszem, przede wszystkim w wymiarze przedstawiania i pojmowania doświadczeń jednostki. Teksty opublikowane z tym zbiorze ukazywały się w 1950 roku w „Echu Tygodnia”5 pod tytułem „Notatki z Węgier”. Zamiana tytułowych „notatek” w wydaniu prasowym na „kartki” w edycji książkowej podkreśla znaczenie ostatniej części dla kompozycji i wymowy tomu.

${ }^{4}$ J. Waligóra, Proza Tadeusza Różewicza, Kraków 2006, s. 72.

5 „Echo Tygodnia” - tygodniowy dodatek do „Gazety Krakowskiej”, organu Komitetu Wojewódzkiego PZPR w Krakowie. 


\section{Kartki z podróży}

Gdy kilka lat później Różewicz wyjechał do Mongolii, a potem do Chin, polityka kulturalna w państwach bloku wschodniego była już inna niż w czasie jego pobytu na Węgrzech, lecz problemy warsztatu literackiego i wiarygodności relacji pozostały jednym z ważniejszych wątków jego podróżopisania. Latem 1956 roku pisarz wraz z międzynarodową grupą dziennikarzy spędził trzy miesiące w Mongolii. Swoje wrażenia z tej podróży opisał w reportażach Niemowa w Mongolii i Kartki z Mongolii oraz niewielkim szkicu $O$ tej porze $e^{6}$. Jesienią 1958 roku na zaproszenie Związku Pisarzy Chińskich wyjechał do Chin. Na miejsce dotarł samolotem z przesiadką w Moskwie, a w czasie trwającego półtora miesiąca pobytu w Kraju Środka odwiedził Chengdu, Chongqing, Hankou, Hangzhou, Szanghaj i Pekin. „Temat chiński” zaowocował rok później reportażem Chiński kalejdoskop (w wydaniu książkowym Sen kwiatu, serce smoka) oraz szkicami Dwa skoki i już Pekin (Kartki z podróży) i Przelot ${ }^{7}$. Niektóre fragmenty tych tekstów Różewicz włączył potem do eseju Tarcza z pajęczy$n y$, a swoje chińskie obserwacje krytycznie podsumował w autobiograficznym i wspomnieniowym artykule $W$ drodze, napisanym w 1985 roku$^{8}$.

Teksty z azjatyckich wypraw Różewicza w warstwie refleksyjno-warsztatowej poruszają dwa główne, ściśle powiązane ze sobą zagadnienia: niepoznawalności innej cywilizacji oraz poszukiwania formy jej literackiego opisu? . Narrator tych utworów kilkukrotnie podkreśla, że czuje się przytłoczony nie tylko skalą i tempem azjatyckich przemian społecznych lub technologicznych, ale przede wszystkim nieprzejrzystością tradycji, kultury i mentalności mieszkańców Mongolii i Chin. „Kartki” pojawiające się w tytułach i podtytułach sugerują fragmentaryczność - problem z adekwatnym i wiarygodnym ucałościowie-

6 T. Różewicz, Niemowa w Mongolii, „Dookoła Świata” 1956, nr 45-47; tenże, Kartki z Mongolii, „Trybuna Wolności” 1956, nr 51; tenże, O tej porze, „Odra” 1959, nr 21. Reportaż Niemowa w Mongolii, opublikowany później w zbiorach prozy Różewicza, to w prasowym pierwodruku Kartki z Mongolii.

7 T. Różewicz, Dwa skoki i już Pekin (Kartki z podróży), „Odra” 1959, nr 43; tenże, Przelot, „Odra” 1959, nr 39.

8 Tenże, $W$ drodze, „Odra” 1986, nr 3.

9 "Literackie ślady po azjatyckich wyprawach Tadeusza Różewicza są świadectwem niemożności wyrażenia mowy obcego świata (zostają jedynie gesty, frazesy, banały) oraz niemożności (i niemożliwości) poznania kultury wyrosłej na zupełnie obcym gruncie, odległej i nieznanej. Są również świadectwem prób pozbycia się - lub choćby "przyciszenia - wpojonych w procesie socjalizacji stereotypów, postaw i przekonań, wyrugowania z siebie przeczytanych książek, zasłyszanych fraz, protekcjonalnego podejścia Europejczyka”. K. Pospiszil, „Widziatem uśmiechnięte twarze”, czyli puste marginesy mowy. Stów kilka o podróżach Tadeusza Różewicza po Chinach [w:] Różewicz: dodawanie, red. E. Bartos, M. Cuber, Katowice 2012, https://depot.ceon.pl/bitstream/handle/123456789/6592/Rozewicz_usmiechniete_twarze.pdf?sequence=1 \&isAllowed=y, dostęp: 18.01.2021. 
niem - zarówno jego indywidualnych doznań i przeżyć, jak i tekstowej relacji przygotowanej dla polskiego czytelnika. Akcentują szablonowość, migawkowość, malowniczość i konwencjonalizację europejskich formuł ujęcia inności, a przede wszystkim ukrytą w nich tendencję do jej postrzegania zależnościowego (europocentrycznego) lub turystycznego. „Kartki” wyrażają także obawę pisarza, że jego realne i osobiste wrażenia z pobytu w Azji są przesłonięte albo zniekształcone kulturowymi kalkami, które nieuchronnie, a nawet niepostrzeżenie nakładają się na faktyczne obserwacje.

Trzy miesiące minęły od chwili, kiedy samolot oderwał się od mongolskiej ziemi. Już wiem, nic nie będzie z mojej starannie zaplanowanej konstrukcji reportażu. Miał to być barwny film, kolorowa taśma długości czterech, pięciu tysięcy kilometrów, które przejechałem do Mongolii.

Przystąpiłem do pisania i konstrukcja się rozpadła. Obrazy, zamiast czekać cierpliwie na swą kolejność, zaczęły się ścigać; te, które miały być na początku, zostały zepchnięte, te, które miały stanowić zakończenie reportażu, wskoczyły do środka. Obrazy zaczęły się zderzać, rozpadać. Nie panowałem już nad nimi, nie mogłem tego materiału zmieścić w przygotowanych formach. Żywa materia sama szukała dla siebie form. I tak to wszystko zostawiłem. Nie tracę nadziei, że rozbite, rozrzucone obrazy zaczną się zbiegać w całość ${ }^{10}$.

Za bramą nagłe stłoczenie domów po obu stronach ulicy. Pierwsze chińskie litery na szyldach. Patrzę na te litery jak na obrazy i dostępny jest dla mnie tylko ich kształt abstrakcyjny. Nic mi nie komunikują. Tak, trudno będzie odczytywać życie, o którym wiem równie mało, a nawet mniej. Zamazane wspomnienia i strzępy lektur raczej zasłoniły mi ten kraj.

(...)

Kiedy myślę teraz, siedząc u siebie w domu, że mam spisać obrazy, które widziałem, ludzi, ich głosy, ich słowa i spojrzenia, ich uczucia ujawnione i nieujawnione - wydaje mi się, że mam wymalować pejzaż. Krajobraz z człowiekiem w środku - na ziarnku ryżu. Na białym ziarenku. Ale nie mam do tego ani odpowiedniego piórka, ani barw, ani umiejętności i... mam bardzo słaby wzrok. Pejzaże, portrety, martwe natury. Czarne obrazy na ziarenkach ryżu oglądałem w Mieście Zakazanym przez rodzaj lupy-mikroskopu ${ }^{11}$.

Teksty z azjatyckich wypraw Różewicza prezentują, obok głównej tematyki, próby uporządkowania doświadczeń reportera, problemy ich intelektualnego i literackiego opracowania, ślady sytuacji biograficznej lub praktyczne okoliczności, które towarzyszyły jego podróżom. To przesunięcie w stronę spraw

10 T. Różewicz, Niemowa w Mongolii [w:] tegoż, Utwory zebrane, t. 2, Wrocław 2004, s. 236.

${ }^{11}$ Tenże, Dwa skoki i już Pekin (Kartki z podróży) [w:] tegoż, Margines, ale..., oprac. J. Stolarczyk, Wrocław 2020, s. 12-13. 
egzystencjalno-warsztatowych było nieprzypadkowe. Kultura polska po „odwilży" nadal podlegała ograniczeniom ideologicznym i politycznym, lecz nie obowiązywała już doktrynalna metoda socrealizmu. Tej szansy nie zmarnowali twórcy, którzy po 1956 roku poszukiwali zarówno nowej tematyki, jak i literackiej formuły pogodzenia informacyjnej funkcji reportażu $\mathrm{z}$ artystyczną poetyką i „prawdą” egzystencjalną. Autor „kartek” z Mongolii i Chin uczestniczył w tych poszukiwaniach. Kilka przemyśleń na temat przemian współczesnego reportażu przedstawił w recenzji Podróży do wielkiego patata Zbigniewa Stolarka, książki o Wietnamie z 1961 roku $^{12}$. Zwrócił uwagę na zacieranie się granic gatunku, przenikanie do niego środków typowych dla prozy poetyckiej, obecność w jego kompozycji elementów dramatu, epiki i liryki, ale równocześnie konieczność zachowania „zwięzłości, lakoniczności, jasności” opisu świata ${ }^{13}$.

„Nowa poetyka reportażu”, proponowana przez Różewicza, nie polega jedynie na przekraczaniu granic gatunków lub rodzajów literackich. „Kartki” z Mongolii i Chin reprezentują cząstkowość, prowizoryczność i hipotetyczność każdej narracji oraz ukryte w niej ideologiczne roszczenia lub niedopowiedzenia, a także jej nieuniknione zapośredniczenie w kulturze, uniwersum komunikacyjnym, innych tekstach lub obrazach. Akcent na to zagadnienie zbliża azjatyckie teksty Różewicza do problematyki szkiców, notatek i felietonów powstających w następnej dekadzie, opublikowanych w zbiorach Przygotowanie do wieczoru autorskiego i Margines, ale..., a z drugiej strony do jego nieepickiej prozy jak Tarcza z pajęczyny czy Śmierć w starych dekoracjach. Z tego punktu widzenia jego reporterska twórczość z lat czterdziestych i pięćdziesiątych jest ogniwem procesu kształtowania się samoświadomości pisarza i jego nowej koncepcji komunikacji literackiej, odpowiadających kryzysowi nowoczesnego paradygmatu w kulturze.

\section{Kartki z warsztatu}

List do Kazimierza Wyki z 13 sierpnia 1973 roku, w którym pisarz zawiadamiał krytyka i przyjaciela o przerwaniu pracy nad powieścią Sobowtór, nie został wysłany. Jak wyjaśniał Różewicz, „list ten "wymieszał się« z kartkami z "warsztatu"” "14. „Sobowtór” miał być powieścią warsztatową i biograficzną, zawierającą fragmenty podróżnicze, dokumentalne i eseistyczne. Nie został ukończony, prawdopodobnie dlatego, że ten projekt pisarz zrealizował w kilku

12 Tenże, Poeta reporterem czy reporter poeta (Na marginesie „Podróży do wielkiego patata” Zbigniewa Stolarka), „Nowa Kultura” 1961, nr 28.

13 Tamże, s. 2.

${ }_{14}$ T. Różewicz, Przygotowanie do wieczoru autorskiego [w:] tegoż, Utwory zebrane, dz. cyt., t. 3, s. 109 . 
innych wybitnych utworach napisanych lub wydanych w tym czasie. Gdyby połączyć minipowieść Śmierć w starych dekoracjach, tom szkiców Przygotowanie do wieczoru autorskiego, dramat Do piachu, prozę autobiograficzno-podróżniczą Strawiony i kilka metaliterackich narracji z początku lat siedemdziesiątych, okazałoby się, że Sobowtór jednak powstał jako suma tych dzieł. Nic z warsztatu pisarza się nie zmarnowało. Każda zapowiadana część czy wersja Sobowtóra została zrealizowana lub powtórnie opracowana i wykorzystana w innych tekstach. Echem tego wieloletniego procesu są również tomy biograficzne Nasz starszy brat i Matka odchodzi, szkice zebrane i wydane w książce Margines, ale..., ostatnie prozy wspomnieniowo-rozliczeniowe, takie jak Drewniany karabin, oraz sukcesywnie ogłaszane fragmenty dziennika. Jako dzieło potencjalne, fragmentaryczne i otwarte, podatne na nowe alternatywne ucałościowienia Sobowtór był poligonem Różewiczowskiego literackiego recyklingu.

Analiza nie-powstania Sobowtóra pozwala uchwycić specyfikę dojrzałej twórczości pisarza: ciągły powrót do źródeł, podstawowych doświadczeń wojennych, politycznych, rodzinnych i artystycznych lub dziennikarskich, kolejnych debiutów i faz twórczości. Ten zabieg umożliwiał Różewiczowi nawiązywanie nowych relacji z własnym dorobkiem, rekontekstualizację wcześniejszych utworów, ożywianie dawnych tematów i zamiarów artystycznych, a dzięki temu nadpisywanie czy wręcz przepisywanie znaczenia swoich tekstów i realizowanej w nich „autobiografii”. Metaforycznie można by powiedzieć, że poeta nieustannie porządkował „kartki” własnego dzieła i przeszłości, żeby je włączyć w następny projekt tekstowo-egzystencjalny, zakotwiczyć w różnych momentach życia i pisarstwa, odpowiednio sprofilować i uwiarygodnić. Ten mechanizm w przybliżeniu ilustrują zmiany Przygotowania do wieczoru autorskiego, tomu, który w pierwszej edycji z 1971 roku miał przede wszystkim charakter eseistyczno-warsztatowy, natomiast w kolejnym wydaniu z 1977 roku Różewicz włączył do niego między innymi opowiadania wspomnieniowe oraz reportaże podróżnicze. Ta korekta uwypukliła, początkowo drugorzędny, referencyjny i fabularny wymiar książki. Trzecia redakcja zbioru, zrealizowana w Utworach zebranych z 2004 roku, została podporządkowana zagadnieniom metaliterackim oraz biografistyce, a przy tym rozszerzona o dwa fragmenty dziennika. Te fragmenty nazwane „kartkami wydartymi z dziennika” są dokumentalną i egzystencjalną sygnaturą całego tomu, a ponieważ Utwory zebrane pozostają najobszerniejszą i ostatnią opublikowaną za życia pisarza edycją większości dzieł - pełnią także funkcję znaczącego domknięcia i podsumowania jego twórczości literackiej oraz prowadzonej w niej narracji autobiograficznej. 


\section{Kartki z dziennika}

„Kartkami” Różewicz nazwał fragmenty dziennika datowane na lipiec-wrzesień 1944 roku, które jako Dziennik z partyzantki (Akcja „Burza”) ukazały się w 2001 roku w miesięczniku „Śląsk" ${ }^{15}$, a następnie w drugim tomie Utworów zebranych. W rękopisie pisarza ten tekst nosił tytuł 30 kartek - wojennego pamiętnika. 30 dni wojny. Echem pierwotnego tytułu dziennika z 1944 są utwory opublikowane wiele dziesięcioleci później, które ich autor określit jako „kartki z dziennika” lub „kartki wydarte z dziennika”.

Kartki wydarte $z$ dziennika Różewicz opublikował w „Odrze” w latach 1984-1985 ${ }^{16}$. Gest wydzielania „kartek” z dziennika powtórzył jeszcze parokrotnie. Fragment pt. Matka odchodzi (kartki z gliwickiego dziennika), zamieszczony z niewielkimi zmianami w tomie Matka odchodzi jako Dziennik gliwicki, ukazał się na łamach „Śląska” w 1995 roku, a Kartki wydarte z dziennika gliwickiego w tym samym piśmie w roku 2004. Część dziennika Różewicza nazywana "dziennikiem gliwickim” i dotąd opublikowana zawiera notatki z drugiej połowy lat pięćdziesiątych. Tematycznie jest poświęcona między innymi przemianom życia kulturalnego w PRL, kwestiom politycznym i literackim, zagranicznym podróżom, chorobie i śmierci Stefanii Różewiczowej z Gelbardów, matki pisarza, oraz śmierci Leopolda Staffa. Kartki wydarte z dziennika zawierają zapiski z lat siedemdziesiątych i pierwszej połowy lat osiemdziesiątych. Są wśród nich notatki warsztatowe, komentarze do lektur, sprawozdania z kontaktów artystycznych lub towarzyskich, listy, opisy spraw codziennych i zwyczajnych. Z roku 1982 pochodzi też zapis wspomnienia Różewicza z wczesnego dzieciństwa, zamieszczony w zbiorze Matka odchodzi pod tytułem Kartka wydarta $z$ dziennika (ten niewielki fragment jest również częścią Kartek wydartych z dziennika dodanych do Przygotowania do wieczoru autorskiego).

Każdorazowo przesłanki wydzielania tych „kartek” i włączania ich do innego dzieła są odmienne. Te, które pisarz zamieścił w zbiorze Matka odcho$d z i$, przedstawiają i dokumentują jego rodzinną historię, a także portretują go jako troskliwego syna, bezsilnego wobec śmiertelnej choroby matki. Te, które weszły do Przygotowania do wieczoru autorskiego, zarówno w wydaniu Prozy z 1990 roku, jak i w edycji Utworów zebranych z roku 2004, można odczytać jako komentarz do historii polskiej kultury w czasach po debiucie Różewicza, krytyczny głos w sprawie powojennych sporów literackich, przyczynek do biografii poety, szkic do jego publicznego i osobistego portretu. Notatki składające się na Kartki wydarte $z$ dziennika zostały nie tylko wyłączone z dziennika, ale miejscami uporządkowane niechronologicznie (chociaż dziennik często był zapisywany na luźnych kartkach, część z lata i jesieni 1982 roku w rękopisie

\footnotetext{
15 Tenże, Dziennik z partyzantki (Akcja „Burza”), „Śląsk” 2001, nr 10.

16 Tenże, Kartki wydarte z dziennika, „Odra” 1984, nr 11.
} 
zachowuje chronologię). Ta operacja wskazuje, że Różewicz decydując się na ich publikację, zamierzał zmienić ich literacki status. Sugerował, że „kartki” nie są już tylko fragmentem oryginalnego dziennika, mechanicznie oddzielonym od jego reszty, lecz innym utworem pod względem budowy i znaczenia.

Kartki wydarte z dziennika, chociaż czas ich powstawania obfitował w istotne wydarzenia w dziejach PRL, nie poruszają wprost tematu polityki lub ówczesnych konfliktów społecznych. Nawet zapiski z 1982 roku, a więc z okresu stanu wojennego, poświęcone są głównie sprawom osobistym lub rodzinnym wspomnieniom, pogodzie, przemyśleniom warsztatowym i planom literackim. Kilka uwag o przeszłości zostało jednak znacząco wplecionych w rozważania o tym, jak minął pisarzowi dzień. Autor dziennika pod datą 26 czerwca 1982 roku zamieścił komentarz o małej wojnie domowej w pierwszych latach po drugiej wojnie światowej, pokoleniu młodzieży, która wyszła z „piekła wojny i okupacji... z prawdziwego, nie malowanego piekła" ${ }^{17}$. Następna notatka, opatrzona tą samą datą, przynosi wspomnienia o zmarłych członkach rodziny, znajomych, przyjaciołach i kolegach z partyzantki. To istotna data w biografii pisarza i pamięci zbiorowej, z którą mierzył się w wielu swoich dziełach. 26 czerwca 1943 roku Różewicz dołączył do leśnego oddziału partyzantki AK, rok później 10 czerwca Gestapo aresztowało jego brata Janusza, natomiast 27 czerwca 1946 roku bezpieka schwytała Stanisława Sojczyńskiego ps. Warszyc, oficera podziemia antykomunistycznego i dowódcę oddziału, w którym wcześniej służył poeta. 30 czerwca 1946 roku Polska Partia Robotnicza przeprowadziła referendum w sprawie zmiany ustroju, stosunków gospodarczych i nowych granic Polski, którego sfałszowane wyniki umocniły komunistyczną władzę w kraju.

„Kartki” z czerwcową sygnaturą przypominały konspiracyjną i partyzancką biografię Różewicza w okresie, gdy pisarz był oskarżany przez publicystów o obojętność na problemy narodowe, rozliczany z postawy patriotycznej, oceniany według kryteriów etycznych, instrumentalnie zawężonych do spraw bieżącej polityki. Jako kolejny powrót do „źródeł” przypominały też jego literackie zaangażowanie po stronie komunizmu w zdecydowanie innej sytuacji historycznej niż czas ich pisania. Autor Kartek wydartych z dziennika opublikował je w latach osiemdziesiątych, dekadzie kształtowania się nowej pamięci zbiorowej o postawie pisarzy w PRL (zwłaszcza w okresie stalinowskim) i umacniania się narodowo-religijnego paradygmatu w kulturze polskiej. Różewicz nie wypierał się swojej przeszłości, lecz zaznaczył, że o doświadczeniu jego pokolenia można wiarygodnie mówić wyłącznie w kontekście „prawdziwego, nie malowanego piekła”.

W tej części dziennika autor powiązał codzienne życie z filozofią, prywatność z wielką historią, a perypetie intelektualistów i artystów z przygodami suki Finki, która przyplątała się do pisarza w czasie spacerów do lasu. Ten „kundel różnych maści i ras" budzi niezobowiązujące zainteresowanie podmiotu-bohatera,

17 Tenże, Przygotowanie do wieczoru autorskiego, dz. cyt., s. 349. 
odczuwającego wzajemną sympatię do zwierzęcia. Aluzja do złożonej tożsamości pisarza (rozwinięta między innymi w Drewnianym karabinie) łączy się w tym fragmencie z perspektywą emocjonalną i poza-ludzką, relatywizującą presję polityki, kultury i historii. Jedynym porządkiem wyraźniej przezierającym przez zapiski Różewicza jest chronologia. „Kartki”, jako fragmenty wyłączone z dziennika i poukładane na nowo, zaburzają ten rytm, a wręcz zapowiadają inne potencjalne sekwencje i ich nowe znaczenia. Ta formuła sprawia, że można z nich ułożyć przeróżne narracje. Każde ucałościowienie przekazu jest jednak - tak jak poprzednie i przyszłe - cząstkowe, doraźne i alternatywne. Co prawda „wydzieranie kartek” jest praktyką autobiograficzną, lecz ostentacyjnie syzyfową, skazaną na powroty, powtórzenia i poprawki, które zapowiadają kolejne, tymczasowo aktualne i uzasadnione rekonstrukcje. Jest również przekroczeniem reguł komunikacyjnych dziennika, umowy diariuszowej, określającej główne założenia jego odbioru: dokumentarność i linearny czas. Jej naruszenie z jednej strony prowadzi do fikcjonalizacji dziennikowej „autobiografii” pisarza, a z drugiej strony przenosi wykreowanego „Różewicza” z porządku pozornie naturalnego do ewidentnie tekstowego i warsztatowego, podtrzymuje jego autokreacyjną sprawczość, odsłania i potwierdza autorską relację z własną przeszłością i dziełem, przeciwdziała ich zawłaszczaniu przez innych, chwilowo uwalnia od zbyt nachalnych zaszufladkowań. Różewicz był wielokrotnie, instrumentalnie wpisywany w różne kategorie i wizerunki. Narzucano mu rolę obcego, dezertera, pisarza nihilistycznego i antyhumanistycznego, oportunisty, postmodernisty, szkolnego klasyka. Gest „wydzierania kartek" podważa tego typu roszczenia, zakłóca domknięte lub pozornie oczywiste narracje o pisarzu, podtrzymuje obecność „Różewicza” w jego dziele w postaci zmiennej i niejednoznacznej.

„Kartki” pojawiały się w prozie Różewicza w różnych okresach jego twórczości, ale dzięki użyciu tej formy pisarz niemal w każdym wypadku stawiał problemy filozoficzne lub artystyczne i warsztatowe. Często za jej pomocą demontował pozornie integralne i esencjonalne światopoglądy epoki, analizował relację cywilizacji z naturą, poprawiał rozproszoną w swoich tekstach „autobiografię” lub powracał do nich jako podmiot ich przekształceń i reinterpretacji. Kryzys podmiotowości, definiowanej i legitymizowanej w wielkich narracjach XX wieku, przełożył się w prozie Różewicza na powstanie nomadycznej figury autobiograficznego „ja” ${ }^{18}$. Figury tożsamości nie postulowanej ani określanej zewnętrznie,

${ }^{18}$ Korzystając wybiórczo z koncepcji Rosi Braidotti, kryzys podmiotowości łączę między innymi z rozkładem pooświeceniowych narracji lub mitów nowoczesności oraz związanych z nimi politycznych i kulturowych reprezentacji człowieka, desakralizacją natury, dążeniem do ucieleśnienia podmiotu, zakwestionowaniem granicy między doświadczeniem społecznym 
lecz utekstowionej, a zatem otwartej i zmiennej, rekonstruktywnej, uchwytnej w literackiej praktyce „recyklingu” dzieła i życiorysu autora stale znajdującego się „w drodze... do samego siebie” 19 .

Kartki z pamiętnika w Echach leśnych dopełniały wzniosłą poetykę partyzanckich nowel, potwierdzały dokumentalny charakter tomu oraz tworzyły jego egzystencjalno-biograficzną ramę, konkretną i pojemną, w której mogły się zmieścić nie tylko akty heroizmu i martyrologii, epatujące literackością spod znaku Juliusza Słowackiego czy Stefana Żeromskiego ${ }^{20}$, lecz także autentyzm żołnierskiego życia, cielesność, pospolitość i niewyparta prywatność. „Kartki” przedstawiające realną, psychologiczną i fizjologiczną kondycję bohaterów Różewicza realizowały też romantyczną wymianę wartości między naturą i cywilizacją. Las i zapuszczona partyzancka ziemianka pełniły w tej prozie funkcję sanktuarium patriotyzmu i człowieczeństwa, a społeczeństwo lub miasto, poddane okupacyjnemu bezprawiu, stawało się przestrzenią niebezpieczeństwa i dehumanizacji.

Natura w pierwszych powojennych reportażach lub reporterskich notatkach Różewicza była przede wszystkim scenerią pracy i modernizacji, a wykorzystanie formy „kartek” sprzyjało dokumentalnemu i wiarygodnemu ujęciu rzeczywistości społecznej, której dziennikarski lub literacki obraz w tym okresie podlegał sukcesywnej ideologizacji. Autor tych tekstów przeciwstawiał się idealizacji oraz egzotyzacji postaci literackiej, usiłował pogodzić postulat opisu przemian technologicznych lub gospodarczych o randze historycznej z wrażliwością na doświadczenie jednostkowe, starał się unikać frazesów gazetowego języka. Kompozycja i reguły komunikacyjne „kartek”, „notatek”, „wspomnień” czy „kalejdoskopu” stwarzały pisarzowi możliwość operowania konkretem i subiektywną bliską perspektywą, pozwalały korygować albo omijać narracje, które przesłaniały świat i człowieka w ówczesnej debacie publicznej lub literaturze.

Autor reportaży z Ziem Odzyskanych mierzył się z jednej strony z mitem piastowskim i nacjonalistycznym programem polonizacji tego terytorium, a z drugiej - z komunistyczną propagandą odbudowy i planów rozwojowych państwa. Notatki i wspomnienia z Czechosłowacji oraz Kartki z Wegier powstawały już po zadekretowaniu w Polsce oficjalnego socrealizmu. Teksty z węgierskiego tomu w większości stanowiły ilustrację stalinowskich reguł perswazji politycznej, modelu historiozofii, pamięci zbiorowej i tradycji, zagadnień industrializacji lub kolektywnego rolnictwa, figur przodowników pracy czy bohaterów ruchu robotniczego. Jeśli pominąć nieliczne fragmenty i dołączone na

i prywatnym, ale nie nawiązuję do myśli feministycznej. Zob. R. Braidotti, Podmioty nomadyczne. Ucieleśnienie i różnica seksualna w feminizmie wspótczesnym, tłum. A. Derra, Warszawa 2009.

19 T. Różewicz, $W$ drodze, dz. cyt., s. 23.

${ }^{20}$ Literacki patronat debiutanckich Ech leśnych Różewicza, sprawowany przez Słowackiego i Żeromskiego, Stanisław Gębala uznał za wybór tradycji mieszczącej się w „zakresie szkolnego kanonu lektur” okresu międzywojennego. S. Gębala, Śmierci piękne i śmierci brzydkie, „Dialog" 1986, nr 11, s. 105 . 
końcu Kartki z dziennika, dominantą tego zbioru na poziomie retoryki oraz systemu wartości były dyskursy modernizacji i humanizmu, używane jednak w przestrzeni publicznej gołosłownie lub instrumentalnie. Tytuł ksiązki, nawiązujący do jej najbardziej osobistej i wiarygodnej części, świadczył o tym, że pisarz próbował literacko uporać się z tym problemem. Jeszcze inne kwestie Różewicz podjął w reportażach i szkicach o tematyce azjatyckiej. Uświadamiając sobie gigantyczną skalę zjawisk, radykalną odmienność i nieprzejrzystość opisywanego świata oraz kulturowe kalki, które zniekształcają lub zawłaszczają spojrzenie reportera, nadał tym tekstom otwartą kompozycję obrazów i wprowadził do nich komentarze warsztatowe.

Luźna struktura i osobisty ton „kartek” ułatwiały Różewiczowi stawianie pytań lub wprowadzanie do tekstów podróżniczych scen, postaci czy wypowiedzi niedopasowanych do wielkich opowieści epoki. Kluga, maszynista statku w reportażu Most ptynie do Szczecina, nie jest papierowym bohaterem mitologii Ziem Odzyskanych, ponieważ w imieniu jego zakorzenienia nad Odrą „przemawiają” nie narodowa czy historyczna racja, definiująca autochtona, lecz regionalny dialekt, doświadczenie wodniaka i fachowa praca. Gdy w trakcie rozmów z wolińskimi rybakami autor reportażu Wyprawa na ztotą rybkę poznaje warunki ich życia w „zdziczałej” poniemieckiej przestrzeni, propagandowe obietnice kierowane do osadników okazują się bajką o „złotej rybce”. Anna, jedna z bohaterek Kartek z Wegier, która udziela polskiemu reporterowi lekcji węgierskiego i odkrywa przed nim traumę po śmierci bliskich w Zagładzie, emanuje osobistym cierpieniem, a nie zadekretowanym optymizmem i wiarą w człowieka. Tymi „szczelinami” Różewicz dodaje do narracyjnego uniwersum stalinizmu głosy słabe, pospolite, peryferyjne lub prywatne, które zachowują ten prozaiczny i nieoficjalny status $\mathrm{w}$,kartkach z notesu reportera”. Nie zderzając się z oficjalną wykładnią dziejów, identyfikacji zbiorowej bądź porządku społecznego, uwierzytelniają jednak diagnozę rzeczywistości i obraz jednostki w jego tekstach.

Szkice i reportaże Różewicza z podróży do Azji są przede wszystkim opisem radykalnej modernizacji, lecz ich równie istotnym tematem jest etyczna i poznawcza postawa autora wobec tego złożonego i nieprzejrzystego zjawiska. Egzotyka pasterskich lub ogrodniczych tradycji czy dane ilościowe, które obrazują zawrotną skalę konsumpcji żywności w Szanghaju, tworzą miarę trudności piętrzących się przed pisarzem. Jego punkt widzenia zmian w Mongolii i Chinach opiera się na sprzeczności. Z jednej strony reporter życzliwie przygląda się reformom społecznym, postępowi technologicznemu i modernizacji obyczajowej w obu krajach, ale z drugiej - dostrzega negatywne skutki tych zjawisk. Jego europejskie doświadczenie każe mu sceptycznie myśleć o wielkich ideach i projektach, które odgórnie zmieniają życie milionów ludzi. Masowa i urzędowa likwidacja takich „szkodników”, jak szczury i wróble, niepokojąco 
przypomina czystki przeprowadzane w XX wieku na populacji ludzkiej ${ }^{21}$. Chociaż Azja uwalnia się od kolonializmu zewnętrznego, na jego miejscu pojawia się państwowa biopolityka. Gwałtowny rozrost metropolii oraz skok cywilizacyjny z gospodarki pasterskiej lub rolniczej do wielkoprzemysłowej łączy się z niepokojącą przemianą krajobrazu i dewastacją środowiska. Urzędowa sekularyzacja oraz kontrola moralności są źródłem przemocy nie tylko w wymiarze symbolicznym.

Mimo że w porewolucyjnych Mongolii i Chinach panuje antyzachodnia propaganda, to właśnie zachodni dyskurs nacjonalizmu, regulacji społecznych oraz eksploatacji zasobów przyrodniczych legitymizuje kategoryczność i totalność prowadzonej w tych krajach modernizacji ${ }^{22}$. Gdy podmiot Różewicza zaczyna wnikać w to, co obce i niezrozumiałe, ogromem i pozorną jednolitością przypominające monolit - okazuje się, że dzieje i kultury opisywanych krajów są jednak hybrydyczne, dotknięte historyczną nieciągłością i zewnętrznymi ingerencjami. Sceptycyzm i niepokój reporterskiego „ja” - ujawniające się w drobnych uwagach, pytaniach bądź skojarzeniach narratora - dochodzą do głosu także w komentarzach warsztatowych, które tłumaczą formalne wątpliwości lub decyzje pisarza. Mierząc się z tymi problemami, Różewicz cofa się przed integralną i dopowiedzianą do końca opowieścią. Tytułami (prasowymi) reportaży sugeruje, że najlepszą metaforą rozmaitości wrażeń z Azji oraz dynamiki ich pamięciowego i literackiego przekształcania byłby „kalejdoskop” lub „kartki”, a dokonując zmian w książkowej edycji tekstów, zachowuje jednak ich początkową strukturę zestawionych „kartek”. Ta kompozycja jest ekwiwalentem dynamicznego stanu Różewiczowskiego podmiotu, który wobec swojej poznawczej i literackiej konsternacji wielokrotnie porzuca percepcję makroskopową na rzecz mikroskopowej i odwrotnie.

„Kartki” jako model otwartej i fragmentarycznej, a w niektórych wypadkach nawet subwersywnej kompozycji - szczególne powiązanej z porządkiem egzystencjalnym - odegrały ważną rolę w ciągle ponawianej pracy Różewicza nad własnym dziełem, powrotem do źródeł i początków twórczości, autorską reinterpretacją śladów biograficznych pozostawianych w jego tekstach lub komentarzach do nich. „Kartki” pozwalały pisarzowi dobrze wykorzystać możliwości

${ }^{21}$ Związki nowoczesnej polityki z praktyką i retoryką „czystki gatunkowej” przeanalizowała Gabriela Jarzębowska w artykule Retoryka deratyzacji w PRL: od czystki etnicznej i politycznej do czystki gatunkowej, „Teksty Drugie” 2018, nr 2.

${ }^{22}$ W długim historycznym oddziaływaniu zachodni imperializm ukształtował między innymi dyskurs natury i środowiska skolonizowanych społeczności w innych częściach świata. Zob. E. DeLoughrey, G.B. Handley, Introduction: Toward an Aesthetics of the Earth [w:] Postcolonial Ecologies: Literatures of the Environment, red. E. DeLoughrey, G.B. Handley, Oxford 2011, https://books.google.pl/books?hl=pl\&lr=\&id=L94SdZygw3IC\&oi=fnd\&pg=PP1\&d$\mathrm{q}=\% 22$ Postcolonial + Ecologies $\% 22++$ content\&ots $=C d 07 X b c f r k \& s i g=1 A d E N V \_N G U x M n-$ R38K2MMvol-JQA\&redir_esc=y\# $\mathrm{v}=$ onepage \&q=\%22Postcolonial\%20Ecologies $\% 22 \% 20$ \%20content\&f=false, dostęp: 18.01.2021. 
literackiego recyklingu, przede wszystkim do reinterpretacji dorobku, swojego miejsca w kulturze i życiorysu. To, co w odbiorze społecznym było zamykane w trywialnych, definitywnych wykładniach - po latach rozbijane i scalane przez Różewicza nabierało nowych znaczeń. To, co podlegało politycznej lub etycznej instrumentalizacji, raz jeszcze stawało się przestrzenią jego aktywnej podmiotowości.

Kształtowanie się kilku wielkich projektów literacko-biograficznych, które wpłynęły na przemiany prozy Różewicza od lat sześćdziesiątych do początku XXI wieku, można powiązać z powstawaniem Sobowtóra. Autor tej powieści przerwał nad nią pracę, lecz nie porzucił pomysłów powstających w jej trakcie. „Kartki” z warsztatu Sobowtóra weszły do różnych jego tekstów lub zostały rozwinięte i przekształcone w inne utwory, tworząc kolejne całości, alternatywne i nieostateczne, a zarazem nadal pozostające potencjalnym materiałem do następnych dzieł powiązanych z niedokończoną powieścią. Analogicznie Różewicz wykorzystał części dziennika. Gest pisarza i stematyzowana operacja „wydzierania kartek" z tego utworu nie tylko prowadziły do powstania osobnych dzieł lub rekonstrukcji istniejących (na przykład Przygotowania do wieczoru autorskiego), ale także uruchamiały jego praktykę tekstowo-egzystencjalną, nastawioną na reinterpretację swojej biografii oraz potwierdzenie podmiotowości.

Tak samo ważna była medialna i wariacyjna funkcja „kartek”. Tadeusz Różewicz za ich pomocą dekomponował swoje narracje, ponownie zestawiał ich części, realizował dawne literackie projekty w kolejnych dziełach, krzyżował główne tematy pisarstwa, a wreszcie łączył autobiograficzną obecność w twórczości z komentowaniem oraz poprawianiem tego, co już napisał lub opublikował. „Kartki” były też śladem procesu pisania, który Różewicz chciał zachować i zaznaczyć w gotowych tekstach. Jego twórczość została zapisana na luźnych kartkach, serwetkach, kalkach, kopertach lub w notesach z powkładanymi dodatkowo kartkami. Na wykorzystanych już stronach pisarz przez dziesięciolecia notował nowe utwory, redagował je lub dopisywał komentarze. „Kartki” są zatem historią jego pracy warsztatowej, związanej z materialnością tekstu i nośnika, a także tropem ich bibliologicznych znaczeñ ${ }^{23}$, które zniknęły w druku.

\section{Bibliografia}

Bornstein G., Jak czytać stronę. Modernizm i materialność tekstu, tłum. J. Sobesto, przekład przejrzał i poprawił T. Kunz, „Wielogłos” 2017, nr 1.

Braidotti R., Podmioty nomadyczne. Ucieleśnienie i różnica seksualna w feminizmie wspótczesnym, tłum. A. Derra, Warszawa 2009.

${ }^{23}$ Zob. G. Bornstein, Jak czytać stronę. Modernizm i materialność tekstu, tłum. J. Sobesto, przekład przejrzał i poprawił T. Kunz, „Wielogłos” 2017, nr 1. 
Browarny W., Nadodrze Tadeusza Różewicza: o reportażu „Most ptynie do Szczecina”, „Czytanie Literatury: łódzkie studia literaturoznawcze” 2013, nr 2.

DeLoughrey E., Handley G.B., Introduction: Toward an Aesthetics of the Earth [w:] Postcolonial Ecologies: Literatures of the Environment, red. E. DeLoughrey, G.B. Handley, Oxford 2011, https://books.google.pl/books?hl=pl\&lr=\&id= L94SdZygw3IC\&oi =fnd \&pg=PP1 \& dq=\%22Postcolonial +Ecologies \%2 $2++$ content $\&$ ots $=C d 07 X b c f r k \& s i g=1 A d E N V \_N G U x M n R 38 K 2 M M v o l-$ -JQA\&redir_esc=y\#v=onepage $\& \mathrm{q}=\% 22$ Postcolonial $\% 20$ Ecologies $\% 22 \% 20$ \%20content\&f=false, dostęp: 18.01.2021.

Gębala S., Śmierci piękne i śmierci brzydkie, „Dialog” 1986, nr 11.

Jarzębowska G., Retoryka deratyzacji w PRL: od czystki etnicznej i politycznej do czystki gatunkowej, „Teksty Drugie” 2018, nr 2.

Pospiszil K., „Widziatem uśmiechnięte twarze”, czyli puste marginesy mowy. Stów kilka o podróżach Tadeusza Różewicza po Chinach [w:] Różewicz: dodawanie, red. E. Bartos, M. Cuber, Katowice 2012, https://depot.ceon.pl/bitstream/handle/ $123456789 / 6592 /$ Rozewicz_usmiechniete_twarze.pdf? sequence $=1 \&$ is Allowed=y, dostęp: 18.01.2021.

Różewicz T., Dwa skoki i już Pekin (Kartki z podróży), „Odra” 1959, nr 43.

Różewicz T., Dziennik z partyzantki (Akcja „Burza”), „Śląsk” 2001, nr 10.

Różewicz T., Kartki wydarte z dziennika, „Odra” 1984, nr 11.

Różewicz T., Kartki z Mongolii, „Trybuna Wolności” 1956, nr 51.

Różewicz T., Margines, ale..., oprac. J. Stolarczyk, Wrocław 2020.

Różewicz T., Most ptynie do Szczecina, „Trybuna Tygodnia” 1947, nr 9.

Różewicz T., Niemowa w Mongolii, „Dookoła Świata” 1956, nry 45-47.

Różewicz T., O tej porze, „Odra” 1959, nr 21.

Różewicz T., Poeta reporterem czy reporter poeta (Na marginesie „Podróży do wielkiego patata” Zbigniewa Stolarka), „Nowa Kultura” 1961, nr 28.

Różewicz T., Przelot, „Odra” 1959, nr 39.

Różewicz T., Spacer po Opolu, „Trybuna Tygodnia” 1947, nr 10.

Różewicz T., Światta na drodze, „Trybuna Tygodnia” 1947, nr 11.

Różewicz T., Utwory zebrane, oprac. J. Stolarczyk, t. 1-3, Wrocław 2004.

Różewicz T., W drodze, „Odra” 1986, nr 3.

Różewicz T., Wyprawa na ztota rybkę, „Trybuna Tygodnia” 1948, nr 33 i 35.

Waligóra J., Proza Tadeusza Różewicza, Kraków 2006. 